\title{
COMPARATIVE RESISTANCE OF IMPROVED MAIZE GENOTYPES AND LANDRACES TO MAIZE WEEVIL
}

\author{
J. SIWALE, K. MBATA ${ }^{1}$, J. MCROBERT ${ }^{2}$ and D. LUNGU \\ Department of Crop Science, School of Agricultural Sciences, University of Zambia, Lusaka, Zambia \\ ${ }^{1}$ Department of Biological Sciences, School of Natural Sciences University of Zambia, Lusaka, Zambia \\ ${ }^{2}$ International Centre for maize and wheat improvement (CIMMYT), Zimbabwe
}

(Received 8 May, 2008; accepted 19 July, 2009)

\begin{abstract}
A comparative study of maize (Zea mays L.) weevil (Sitophilus zeamais Motsch.) resistance in selected landraces and improved genotypes of maize, was conducted through a field experiment and laboratory assays. The maize grain characteristics that confer resistance to the maize weevil, Sitophilus zeamais Motschulsky, namely; grain hardness, weight and protein content, were compared in 50 improved maize genotypes developed by CIMMYT and two landraces (Cimambwe and Pandawe). The relative susceptibility of all maize experimental material to the weevil, were also compared using Dobie's susceptibility indices, grain weight loss and median development period. Genotypes were significantly different $(\mathrm{p}<0.05)$ for grain hardness but not for protein content. Genotypic differences in grain weight loss due to feeding by larval and adult $S$. zeamais were highly significant $(\mathrm{P}<0.001)$. The genotypes did not differ significantly $(\mathrm{P}>0.05)$ in the Dobie's indices of susceptibility but exhibited a wide index range (0.77 to 9.11). The landrace, Chimambwe, had the second highest Median Development Period, while Pandawe, had the heaviest kernels, though without noticeable advantage in resistance to the weevil. The Open Pollinated Varieties (OPVs) were not superior to hybrids according to the Dobie's index of susceptibility. The possibility of developing maize hybrids or OPVs that are as resistant to the maize weevil, $S$. zeamais, as or even better than landraces is discussed and recommendations made.
\end{abstract}

Key Words: Open pollinated, Sitophilus zeamais, Zambia, Zea mays

\section{RÉSUMÉ}

Une étude comparative de résistance aux charançons de maïs (Zea mays L.) Curculionoidea (Sitophilus zeamais Motsch.) des cultivars traditionnels sélectionnés et les génotypes améliorés de maïs avait été réalisée à travers un champ expérimental ainsi que l'expérience et de laboratoire. Les caractéristiques de grains de maïs qui confèrent la résistance aux charançons de maïs à savoir, Sitophilus zeamais Motschulsky, dureté de grain; les poids et les contenu en protéines, avait été comparés pour 50 génotypes de maïs améliorés, développés par CIMMYT et deux cultivars traditionnels (Cimambwe et Pandawe). La relative sensibilité aux charançons de tout le matériel expérimental de maïs avaient également été comparé à l'aide de l'indices susceptibilité de Dobie, perte de poids de grain et la période médiane de développement. Les génotypes étaient significativement différents $(\mathrm{p}<0,05)$ pour la dureté de grains mais pas pour la teneur en protéine. Les différences génotypique en perte de poids grain en raison de la nutrition de larves et des adultes de $S$. zeamais. étaient hautement significative $(\mathrm{P}<0,001)$. Les génotypes n'ont pas différé significativement $(\mathrm{P}>0.05)$ dans les indices susceptibilité de Dobie de mais présentaient une gamme large d'index $(0,77$ à 9,11). Le cultivar traditionnel, Chimambwe, avait la deuxième plus longue période de développement médian, tandis que Pandawe avait les plus lourds amandes, pourtant sans avantage notable dans la résistance au charançon. Les variétés à pollinisation ouvert (OPVs) n'étaient pas supérieures aux hybrides conformément à l'index de susceptibilité de Dobie. La possibilité de développer des hybrides de maïs ou 
OPVs qui sont aussi résistants aux charançons de maïs, S. zeamais, comme ou même mieux que les cultivars traditionnels est discutée et les recommandations formulées.

Mots Clés: Pollinisation ouverte, Sitophilus zeamais, Zambie, Zea mays

\section{INTRODUCTION}

Maize is the third most produced cereal after wheat and rice in the world. Its principle uses are human consumption and stock feed (Poehlman and Sleper, 1995). In Zambia, maize is the number one cereal in production followed by irrigated wheat (Zulu et al., 2000). The national yield of maize is low and is estimated at 1.5 tonnes per hectare (Pingali, 2001). Commercial yields of maize in the country are well below their potential which are estimated to be in the range of $8.5 \mathrm{tha}^{-1}$ for early maturing open pollinated varieties to $9.7 \mathrm{t}$ $\mathrm{ha}^{-1}$ for intermediate to late maturing hybrids (Vivek et al., 2005).

The low maize yields in Zambia and elsewhere in Africa are due to biotic and abiotic stresses on the crop. The International Maize and Wheat Improvement Centre (CIMMYT), in Harare, Zimbabwe, has classified maize production areas in Africa, into ecological zones and has documented the biotic and abiotic stresses that cause low maize yields in the zones. Zambia belongs to the mid-altitude, sub-tropical ecological zone within the sub-Saharan African region. Abiotic stresses depressing maize yield in this zone are low and declining soil fertility and drought. The biotic stresses include Gray Leaf Spot disease, streak virus disease, and damage by insect stem borers (Chilo and Sesamia spp.) and other insects including maize weevils. The latter infest maize while the crop is still in the field (Cardwell et al., 2000; Kim and Kossou, 2003; Pendleton et al., 2005; Asawalam and Hassanali, 2006) and destroy the crop during storage (Pingali, 2001).

Despite the increased understanding of the inheritance of weevil resistance and of the resistance mechanisms in the maize grains, there has been very little application of this knowledge in maize breeding programmes (Dhliwayo and Pixley, 2002). Very little work has been done on breeding for maize weevil resistance in storage. In their study of maize weevil resistance involving two synthetic populations and four bi-parental populations, Dhliwayo and Pixley (2002) found that it was possible to improve weevil resistance in maize during storage using conventional breeding methods.

The objectives of this study were to (i) compare the resistance of selected landrace and improved maize genotypes, to the maize weevil Sitophilus zeamais, and (ii) characterise grain traits that confer this resistance in the maize genotypes.

\section{MATERIAL AND METHODS}

Study area. A field experiment was set up at Golden Valley Agricultural Research Trust (GART) Station, $80 \mathrm{~km}$ north of Lusaka, Zambia, during the 2005 - 2006 growing seasons, to multiply the selected landrace and improved maize genotypes for laboratory weevil bioassays and biochemical tests. The experimental set-up was also to advance the $\mathrm{F}_{1}$ hybrids materials in the study to $F_{2}$, the generation normally stored by farmers and which is what should therefore be resistant to the maize weevil damage (Munjoma, 2004).

The Station is located at Latitude $14^{\circ} 40^{\prime}$ South and Longitude $25^{\circ} 01^{\prime}$ 'East, and at $1140 \mathrm{~m}$ above sea level. The soil type is described as Makeni Series, which is a fine, mixed isohyperthemic ultic Paleustalf (Ti jmons, 1988). According to the World Reference Base (WRB), this soil is categorized as a Chromic luvisol (FAO, 1998).

Field experiment. Thirty-five $F_{1}$ hybrids and 15 Open Pollinated Varieties (OPVs) of maize obtained from CIMMYT and that had in previous studies been classified into various resistance group categories, were used in this study. Furthermore, two local varieties (landraces) from Mbala district of northern Zambia were also included in the experiment (Table 1). The two landraces are locally called Pandawe and Chimambwe. The description of these landraces is given in Table 2 . 


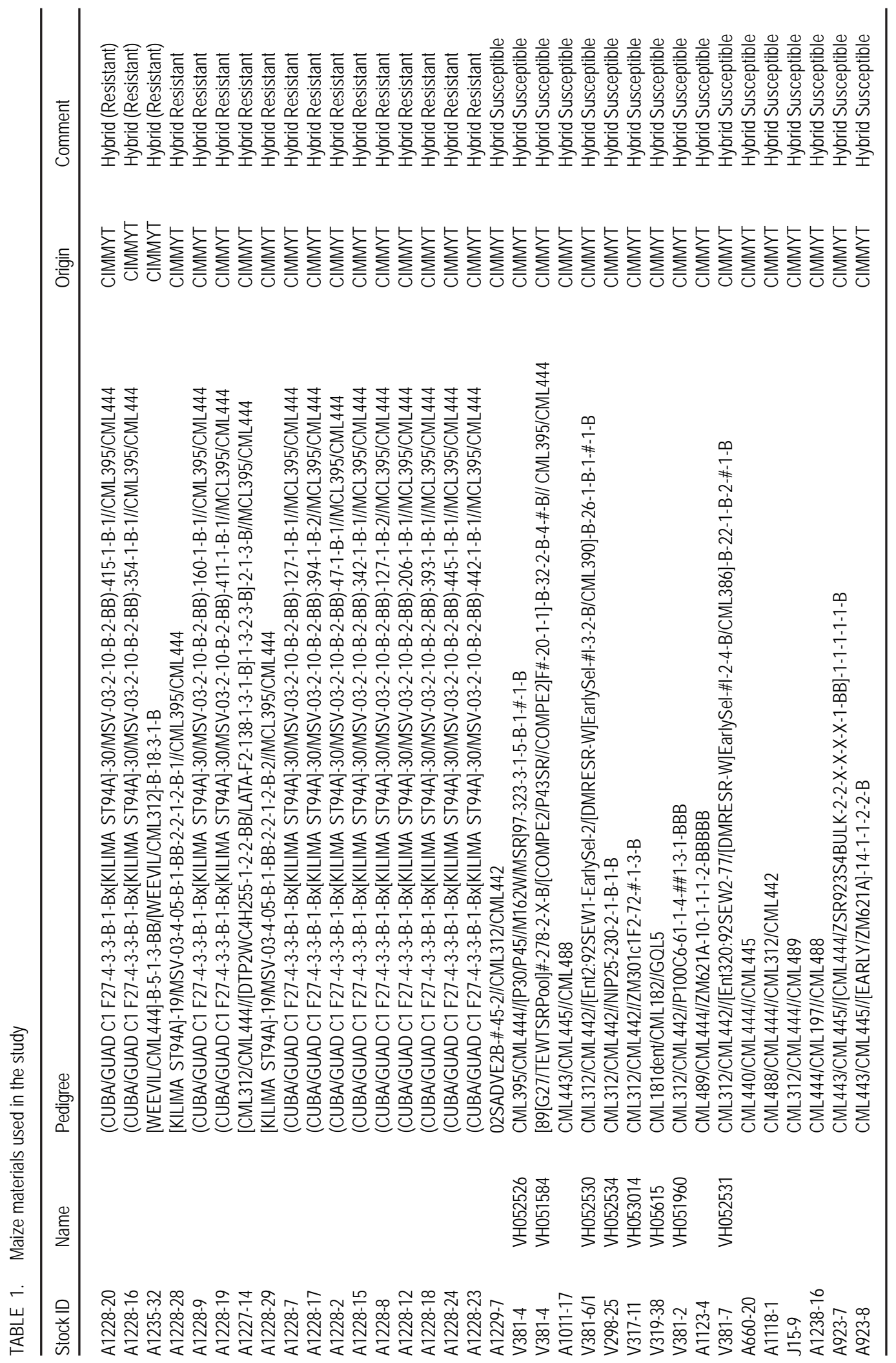




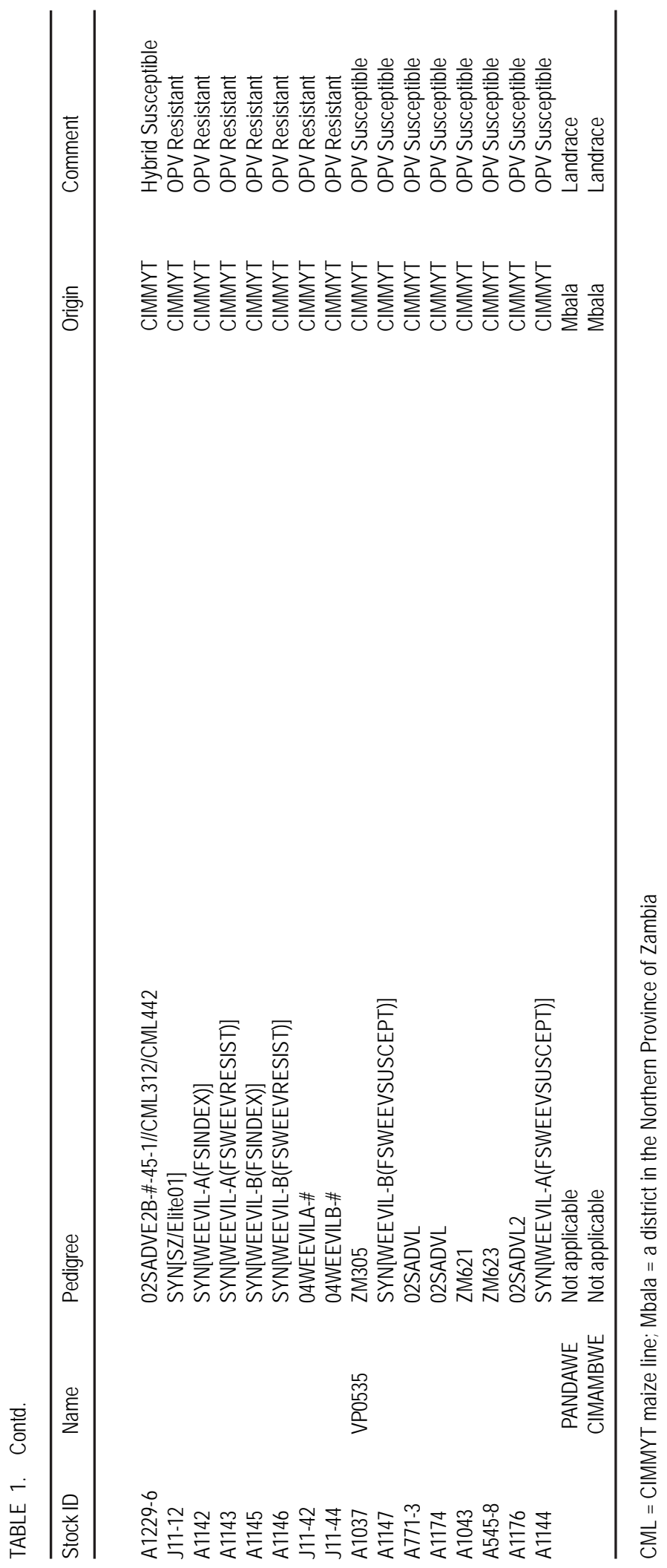




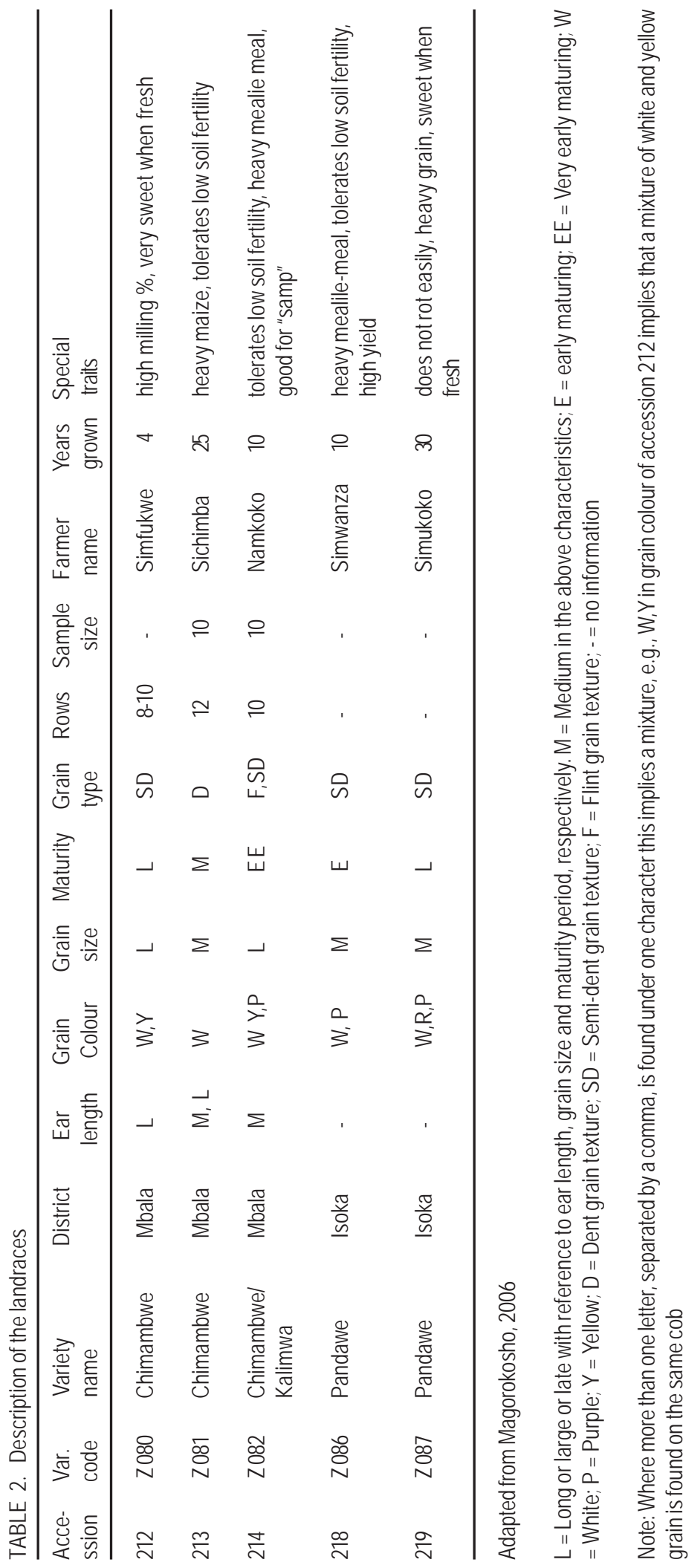


A field experiment was laid out using a randomised complete block design with 3 replications. Each plot consisted of 4 rows measuring $5 \mathrm{~m}$ long. The inter- and intra-row spacing was $90 \mathrm{~cm}$ and $25 \mathrm{~cm}$, respectively. Two maize seeds were planted per station. In addition to the standard crop management practices for maize, furadan was applied pre-plant in planting holes for the control of cutworms and stem borers; azodrin was applied against stalk borers, and confidor (imidacroprid) was applied at grain filling stage for the control of termites, which had already caused wide spread damage in the neighbouring maize trials. Methomyl, a carbamate, was applied against the armoured cricket Acanthoplus speiseri Brancsik, a pest of grain crops, common in the study area and elsewhere in central Zambia. Atrazine was applied for weed control and supplemented with hand weeding.

For weevil evaluation, 12 plants were isolated from the two middle rows in each plot and upper ears covered with plastic bags to prevent pollination. Pollen was collected from the isolated plants, bulked and then used to pollinate the same plants (12 plants). Where plant emergence was poor, the number of isolated plants was less than 12.

Laboratory assays. The maize weevils used in this study were collected from bags of weevilinfested maize, harvested from field trials at Mount Makulu Central Research Station, Chilanga, Zambia, during the previous growing season. The genotypes that were multiplied at GART were evaluated for maize weevil resistance by maize weevil bioassays using a modified Dobie's method (Dobie, 1977; Serratos et al., 1993). This was conducted at Mount Makulu Central Research Station.

Three cobs of each genotype were handshelled and the grain packed into $5 \times 8$ polythene bags. The bags were closed with rubber bands and then stored in a deep freezer for one week to kill any previous infestation by insects, including adults, larvae or eggs (Kossou et al., 1993). The temperature in the freezer was minus $-16^{\circ} \mathrm{C}$.

Samples of $50 \mathrm{~g}$ of grains of each genotype were taken into new 350-ml plastic jars. These jars, purchased from Polymer Mouldings Limited in Lusaka, measured $11.7 \mathrm{~cm}$ in height and about
$5.2 \mathrm{~cm}$ in diameter at the mouth. The tops of the lids of these jars were cut out, leaving only the screw-top rings. Forty unsexed weevils of mixed age, initially counted into vials with the help of pairs of tweezers and a Denominator MultipleTally tally counter (The Denominator Company, Inc. Woodbury, Connecticut, USA) were poured into each jar.

To close the jars after the introduction of weevils, a piece of calico cotton cloth, $15 \mathrm{~cm}$ x 15 $\mathrm{cm}$, was put on top of the jar and the ring of the lead screwed on to the jar over the cloth or the cloth was fastened to the jar with a rubber band. The cotton cloth was used to prevent the weevils from escaping and to provide ventilation.

Grain of SC 513 maize variety from Seedco, an international seed company operating in Zambia, was included in the experiment as a susceptible variety check. This brought the total number of treatments to 53 . Genotype entry numbers written on stickers were used to label the jars.

The jars were placed in controlled temperature and relative humidity room and laid out in an RCBD with each shelf constituting a block. The temperature in the room was maintained at $29 \pm 1$ ${ }^{\circ} \mathrm{C}$ by a thermostat-controlled heater mounted on a wall. The relative humidity ranged from 43 to $60 \%$; the humidity being provided by water placed in four troughs (Bekele and Hassanali, 2001).

After an oviposition period of ten days, the adult (parents) maize weevils were removed from the samples by sieving with a Standard U.S.A. Testing Sieve set (VWR Scientific, West Chester, PA 19380,U.S.A.). The powder, where present, went through the No.8 (2.36 mm mesh opening) and the No. 18 (1.00 mm opening) and collected in the pan. Weevils went through the No 8 sieve and were collected on the No. 18 sieve; while the grain remained on the No. 8 sieve.

Live and dead weevils were counted using tweezers and a tally counter. Tweezers were also used to probe immobile weevils to establish whether they were dead. Weevils, like some other beetles, tend to feign death when disturbed (Baker,2007).

Sieving and checking for emergence of the $F_{1}$ progeny started 3 weeks following the removal of the parents (Serratos et al., 1993). Sieving and counting the $\mathrm{F}_{1}$ progeny was done every 2 days (Derera et al., 2001) and the sieved insects were 
discarded. This interval of counts did not pose a risk of the $F_{1}$ progeny laying eggs in the maize samples to produce the $\mathrm{F}_{2}$ generation, considering the fact that individuals of Sitophilus zeamais do not mate before they are three days old (Danho et al., 2002).

Physical and biochemical parameters. Important maize kernel physical and biochemical parameters that have been reported to confer resistance to the maize weevil in the literature (Arnason et al., 1997) were analysed using appropriate methods. These parameters were grain hardness, protein content and kernel weight.

Grain hardness. Grain hardness test was done by weighing a sample of $50 \pm 0.1 \mathrm{~g}$ of maize kernels for each genotype. The sample was ground in a Retsh Laboratory Mill, Type ZM 1000 (GmbH \& Co. KG 5657 HAAN 1, Germany). The grinding was done in two stages. During the first stage, the mill was set at 10,000 revolutions per minute (RPM) and 1 minute time setting for duration, with the sieve removed. This was done just to break the kernels into smaller fragments to make the next stage easier. The collected fragments were put back into the hopper and the number 11 sieve replaced. The speed and time setting was the same as above. The collected meal was put back in labelled plastic bags. The meal was then hand-sifted in a $0.5 \mathrm{~mm}$ DIN 4188 sieve (ANALYSENSIEB Retsck, W. Germany).

The collected flour and retained grit were emptied in separate labelled $5 \mathrm{~cm}$ x $8 \mathrm{~cm}$ white plastic bags, and these were subsequently weighed and data recorded. The weight of the grit and flour were added together for each genotype to get the total weight, which was about the same as the original weight of the grain from where the flour and grit samples were derived. Grain hardness was expressed as percent grit of the total weight of the sample (grit plus flour after sieving a $50 \pm 0.1$ g ground maize sample). Thus, grit percentage was the proxy for grain hardness.

Kernel weight. The number of kernels contained in a $50 \pm 0.1$ g grain sample of each genotype was determined and this number was divided into 50 $\mathrm{g}$ to obtain the weight per kernel.
Protein content. Twenty-grammes samples of whole maize kernels were ground in a laboratory mill for each genotype. Protein content was determined using the Kjeldahl procedure.

Dobie's Susceptibility Index. The Dobie index of susceptibility was used as the criterion to separate genotypes into different resistance groups (Dobie, 1977; Gudrups et al., 2001; Dhliwayo and Pixley, 2003). The index is given by the formula:

I = $100 \log$ e (no of adult weevil progeny emerged)/ MDP.

Where: I = Dobie's Susceptibility Index

MDP $=$ Median Development period, and this is the period (days) from the middle of the oviposition period to the middle of the emergence (i.e. 50 percent emergence) of the $\mathrm{F} 1$ progeny.

Log e (sometimes written as $\log n)=$ the natural logarithm.

The Dobie Index was then used to classify the genotypes into susceptibility groups following the scales used at CIMMYT in Zimbabwe (Pixley, 1997) which were as follows:

Dobie index of $\leq 4$ was classified as resistant; Dobie index of 4.1 to 6.0 was moderately resistant;

Dobie index of 6.1 to 8.0 was moderately susceptible;

Dobie index of 8.1 to 10 was susceptible; and Dobie index of $>10$ was classified as highly susceptible.

Statistical analyses. The Analysis of Variance (ANOVA) for all the measured parameters was done using the Mstat-C Programme (Freed et al., 1988). Total progeny emergence data were transformed to log base 10 before subjecting them to ANOVA (Dhliwayo and Pixley, 2003). Before conducting the log transformation, a value of 1 was added to all data points because of the presence of zeros in some data points in the data set. The mean separation, in cases where there were significant differences among treatments, 
was done using LSD (0.05) to facilitate the comparison of all pairs of treatment means (Montgomery, 2001).

\section{RESULTS}

Protein content. Genotypes were not significantly different $(\mathrm{P}>0.05)$ for protein content (Table 3). However, when the top 5 and least 5 genotypes in protein content in each group (hybrids and OPVs) were considered, it was found that resistant genotypes had a tendency of containing higher levels of protein than susceptible ones (Table 4).

Grain hardness. Grain hardness showed discrimination among the 52 genotypes $(\mathrm{P}<0.05)$. However, genotypes exhibited a higher or lower degree of hardness regardless of whether they were hybrids or OPVs. The two landraces were ranked low in hardness in relation with the top 5 hybrids and 5 OPVs. Separation of the genotypes into groups of the top 5 and the least 5 in grain hardness again showed that most of the harder genotypes were from the resistant class (Table 5).

Parent survival. Table 6 presents the number of live weevils out of the 40 introduced in each sample. The difference is the number of weevils that were found dead in each incubation jar per genotype. The overall mean survival number for the parent weevils at the end of the oviposition period was 13.5 , while the range was 4.0 to 33.7 weevils.
TABLE 4. Comparative protein content between the best and the worst genotypes

\begin{tabular}{|c|c|c|}
\hline Entry & Protein content & Classification \\
\hline \multicolumn{3}{|l|}{ Hybrids } \\
\hline \multicolumn{3}{|c|}{ Top 5} \\
\hline 27 & 11.4 & Susceptible \\
\hline 19 & 11.2 & Resistant \\
\hline 13 & 10.9 & Resistant \\
\hline 12 & 10.7 & Resistant \\
\hline 1 & 10.6 & Resistant \\
\hline \multicolumn{3}{|c|}{ Least 5} \\
\hline 4 & 9.0 & Resistant \\
\hline 35 & 9.0 & Susceptible \\
\hline 10 & 8.6 & Resistant \\
\hline 7 & 8.5 & Resistant \\
\hline 24 & 8.3 & Susceptible \\
\hline \multicolumn{3}{|c|}{ OPVs } \\
\hline \multicolumn{3}{|c|}{ Top 5} \\
\hline 37 & 10.8 & Resistant \\
\hline 42 & 10.6 & Resistant \\
\hline 47 & 10.6 & Susceptible \\
\hline 36 & 10.5 & Resistant \\
\hline 48 & 10.0 & Susceptible \\
\hline \multicolumn{3}{|c|}{ Least 5} \\
\hline 45 & 9.0 & Susceptible \\
\hline 40 & 8.9 & Resistant \\
\hline 44 & 8.9 & Susceptible \\
\hline 49 & 8.3 & Susceptible \\
\hline 50 & 8.3 & Susceptible \\
\hline \multicolumn{3}{|c|}{ Landraces } \\
\hline Pandawe & 9.2 & Unknown \\
\hline Chimambwe & 10.0 & Unknown \\
\hline Mean & 9.8 & \\
\hline LSD (5\%) & 2.6 & \\
\hline
\end{tabular}

TABLE 3. Analysis of variance table of protein content of all 52 genotypes

\begin{tabular}{lccccc}
\hline Source & Degrees of freedom & Sum of squares & Mean square & F-value & Prob. \\
\hline Block & 2 & 12.01 & 6.006 & 2.38 & 0.0976 \\
Entry & 51 & 95.51 & 1.873 & 0.78 & 0.8801 \\
Error & 102 & 257.32 & 2.523 & & \\
Non-additivity & 1 & 9.07 & 9.069 & 3.69 & \\
Residual & 101 & 248.25 & 2.458 & & \\
Total & 155 & 364.84 & & & \\
\hline
\end{tabular}

Grand Mean $=9.801 \sim$ Grand Sum $=1529.000 \sim$ Total Count $=156$. Coefficient of Variation $=16.21 \%$ 
TABLE 5. Comparative hardness between the top 5 and the least 5 genotypes

\begin{tabular}{|c|c|c|}
\hline Entry & Grit (\%) & Classification \\
\hline \multicolumn{3}{|l|}{ Hybrids } \\
\hline \multicolumn{3}{|c|}{ Top 5} \\
\hline 9 & 72.3 & Resistant \\
\hline 6 & 71.8 & Resistant \\
\hline 1 & 71.4 & Resistant \\
\hline 13 & 71.2 & Resistant \\
\hline 8 & 71.1 & Resistant \\
\hline \multicolumn{3}{|c|}{ Least5 } \\
\hline 27 & 62.9 & Susceptible \\
\hline 26 & 62.6 & Susceptible \\
\hline 24 & 61.0 & Susceptible \\
\hline 33 & 60.0 & Susceptible \\
\hline 25 & 59.7 & Susceptible \\
\hline \multirow{2}{*}{\multicolumn{3}{|c|}{$\begin{array}{l}\text { OPVs } \\
\text { Top5 }\end{array}$}} \\
\hline & & \\
\hline 39 & 74.0 & Resistant \\
\hline 48 & 71.3 & Susceptible \\
\hline 41 & 71.2 & Resistant \\
\hline 46 & 71.0 & Susceptible \\
\hline 43 & 70.0 & Susceptible \\
\hline \multicolumn{3}{|c|}{ Least5 } \\
\hline 36 & 67.5 & Resistant \\
\hline 50 & 66.6 & Susceptible \\
\hline 37 & 66.3 & Resistant \\
\hline 49 & 65.8 & Susceptible \\
\hline 40 & 65.4 & Resistant \\
\hline \multicolumn{3}{|c|}{ Landraces } \\
\hline Pandawe & 62.6 & Unknown \\
\hline Chimambwe & 63.9 & Unknown \\
\hline Mean & 67.76 & \\
\hline LSD (5\%) & 6.65 & \\
\hline
\end{tabular}

Progeny emergence. Emergence of the $F_{1}$ progeny was different among genotypes. Figure 1 shows an $F_{1}$ adult progeny emerging from a kernel and an exit hole left by another $\mathrm{F}_{1}$ adult weevil. The total of all the $\mathrm{F}_{1}$ progeny adult weevils for each genotype is presented in Table 6. The grand emergence mean was 13.43 and the range was 1.67 for entry number 8 and 50 to 86.67 weevils for the susceptible check. For the total weevil emergence data, the differences were highly significant $(\mathrm{P}<0.001)$ but for the transformed data, the differences were not significant $(\mathrm{P}>0.05)$.
Grain weight loss. The greatest weight loss of 8.563 g occurred in entry 53, a susceptible check (Table 6), while the lowest weight loss of $1.7 \mathrm{~g}$ was recorded in entry number 2 .

Dobie index of susceptibility. The Dobie Index of susceptibility ranged from 0.77 for entry numbers 8 and to 9.11 for the susceptible check (Table 6). The trial mean was 3.77. However, the Dobie index re-classified the susceptible genotypes to be resistant or moderately resistant, except for the check which was susceptible (Table 7).

\section{DISCUSSION}

Protein content. Although genotypes were not statistically different for protein content (Table 1 ), a closer look at the best 5 and worst 5 genotypes revealed a tendency for genotypes with higher protein content to be resistant (based on the classification of the genotypes done at CIMMYT, Zimbabwe). This is consistent with what other investigators have found (Derera et al., 2001; Dhliwayo and Pixley, 2003; Garcia-Lara et al., 2004). The fact that protein content did not have a definite relationship with physical resistance parameters in this study may indicate that there are other resistance factors in maize studied. Arnason et al. (1994; 1997) reported the presence of biochemical compounds, particularly ferulic acid in the kernels.

Grain hardness. The differences among genotypes for grain hardness in this study were expected when there is a large number of genotypes in an experiment being evaluated. This is so because the genotypes had different grain textures. When grinding grain samples, genotypes with softer endosperms yielded more flour than those with harder endosperms. Grain hardness was closely related to maize weevil resistance (Table 5). These results are consisted with those of Leuschner et al (2000), who reported a distribution of larger numbers of Sitophilus oryzea progenies among genotypes of pearl millet (Pennisetum glaucum L) that had a higher proportion of soft endosperm. 


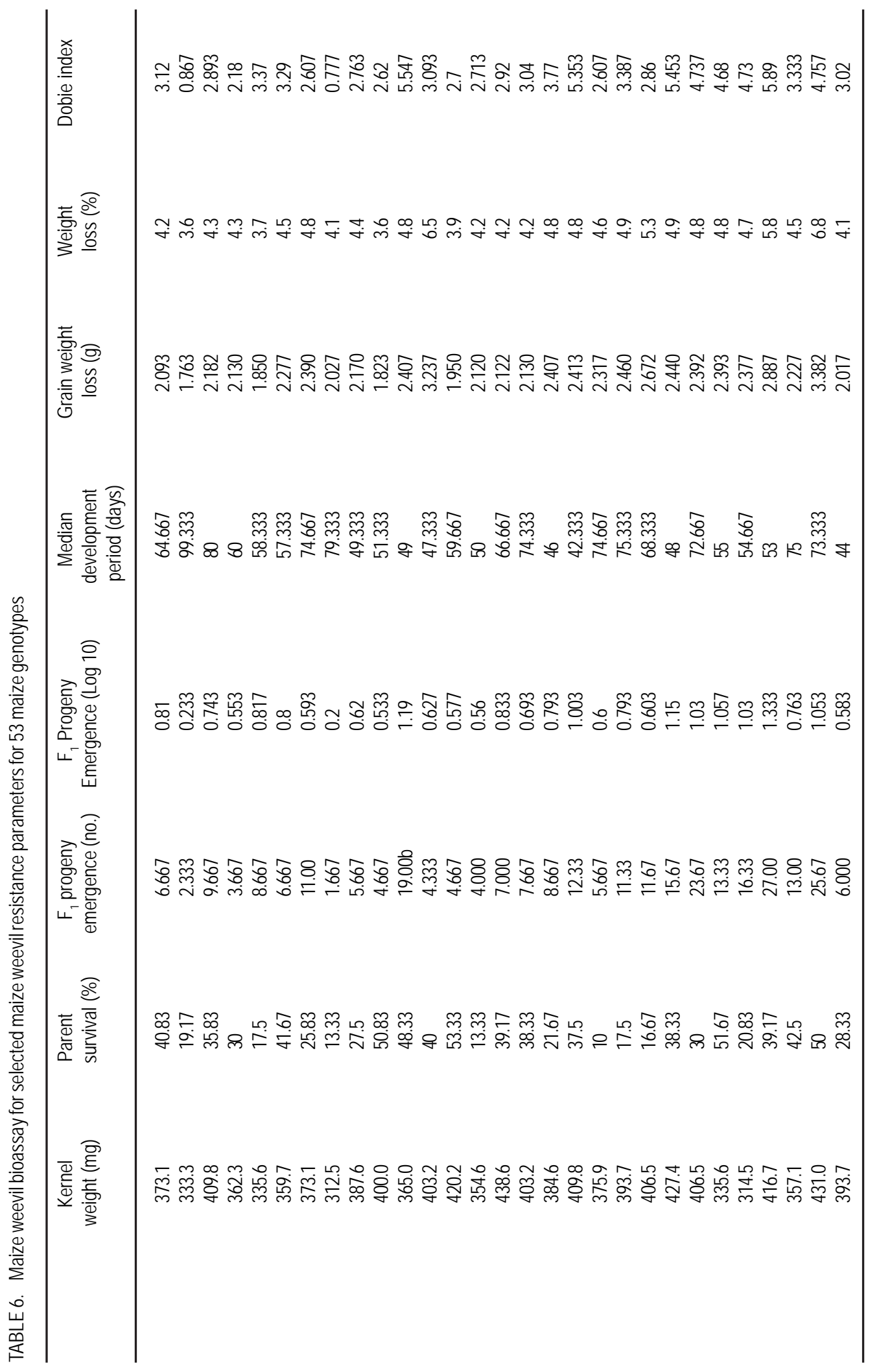


Resistance of improved maize genotypes and andraces to maize weevil

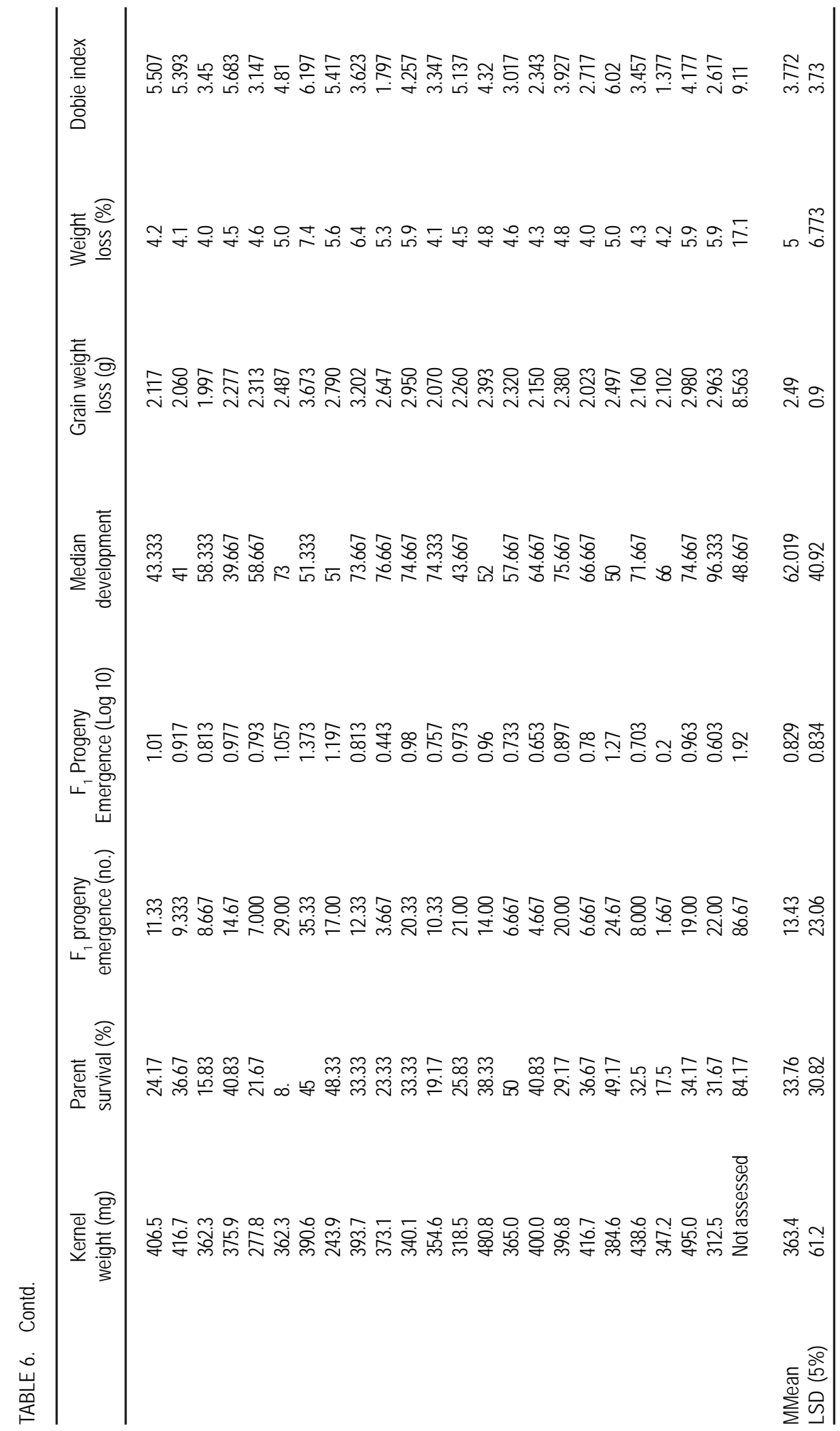




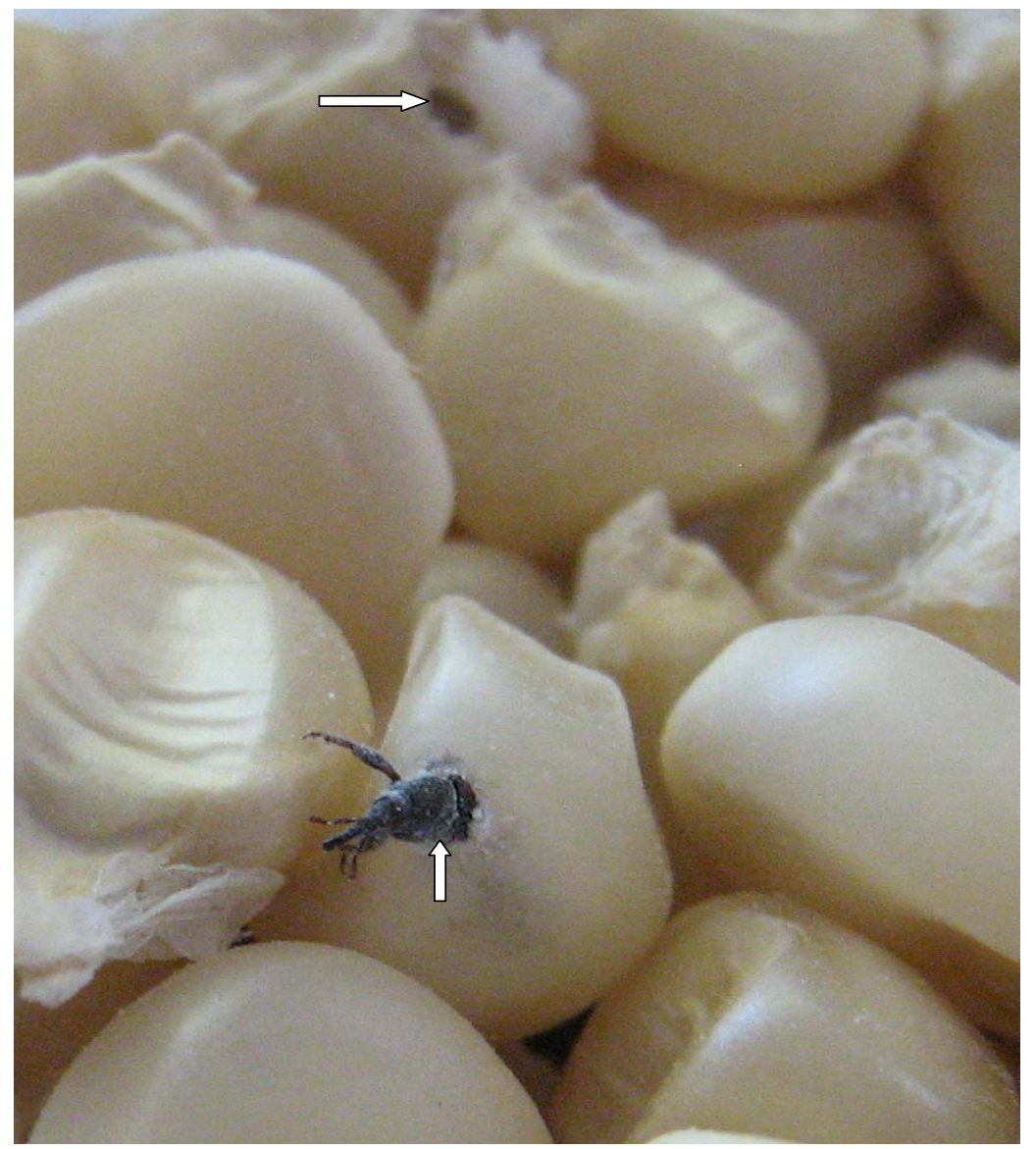

Figure 1. An $\mathrm{F}_{1}$ adult weevil progeny emerging from a kernel (lower arrow) and an emergence hole left by another weevil (upper arrow).

Parent survival. Parent weevil survival tended to be higher in susceptible than resistant genotypes. Thus, the susceptible check had the highest number, 33.7, of surviving parent weevils compared to the trial mean of 13.5. The larger number of parental survival generally leads to a larger number of eggs and ultimately the $\mathrm{F}_{1}$ progeny. The susceptible check yielded $86 \mathrm{~F}_{1}$ progeny compared to a grand mean of 13 and means of less than 1 in treatment 2 and 8 (Table $6)$.

Progeny emergence. Progeny emergence tended to be higher in susceptible genotypes than in resistant ones (Garcia-Lara et al., 2004). In this study, the susceptible check had the highest number of the total $\mathrm{F}_{1}$ emergence, numbering up to 87 weevils, against the experimental mean of
13 weevil emergencies. The total $F_{1}$ progeny emergence may have been reduced in the whole experiment by mechanical disturbance of the samples through the action of sieving every 2 days (Ungunantwiwat and Mills, 1979).

Median development period (MDP). The median development period in this study was very high, ranging from 39.667 in entry number 33 , to 99.3 in entry number 2 (Table 6). Other workers have reported lower ranges MDPs, for example, MDP ranges of about 4 to 40 days. The longer MDPs in this study may be attributed to the less than optimal relative humidity in the constant climate room.

Grain weight loss. The highest loss again occurred in the susceptible check, in which $8.5 \mathrm{~g}$ 
TABLE 7. Comparative classification of maize to maize weevil resistance using Dobie index

\begin{tabular}{|c|c|c|c|}
\hline Class & CIMMYT classification & Dobie index & New classification $\$$ \\
\hline Hybrid & Resistant & 3.12 & Resistant \\
\hline Hybrid & Resistant & 0.867 & Resistant \\
\hline Hybrid & Resistant & 2.893 & Resistant \\
\hline Hybrid & Resistant & 2.18 & Resistant \\
\hline Hybrid & Resistant & 3.37 & Resistant \\
\hline Hybrid & Resistant & 3.29 & Resistant \\
\hline Hybrid & Resistant & 2.607 & Resistant \\
\hline Hybrid & Resistant & 0.777 & Resistant \\
\hline Hybrid & Resistant & 2.763 & Resistant \\
\hline Hybrid & Resistant & 2.62 & Resistant \\
\hline Hybrid & Resistant & 5.547 & Moderately resistant \\
\hline Hybrid & Resistant & 3.093 & Resistant \\
\hline Hybrid & Resistant & 2.7 & Resistant \\
\hline Hybrid & Resistant & 2.713 & Resistant \\
\hline Hybrid & Resistant & 2.92 & Resistant \\
\hline Hybrid & Resistant & 3.04 & Resistant \\
\hline Hybrid & Resistant & 3.77 & Resistant \\
\hline Hybrid & Susceptible & 5.353 & Moderately resistant \\
\hline Hybrid & Susceptible & 2.607 & Resistant \\
\hline Hybrid & Susceptible & 3.387 & Resistant \\
\hline Hybrid & Susceptible & 2.86 & Resistant \\
\hline Hybrid & Susceptible & 5.453 & Moderately resistant \\
\hline Hybrid & Susceptible & 4.737 & Moderately resistant \\
\hline Hybrid & Susceptible & 4.68 & Moderately resistant \\
\hline Hybrid & Susceptible & 4.73 & Moderately resistant \\
\hline Hybrid & Susceptible & 5.89 & Moderately resistant \\
\hline Hybrid & Susceptible & 3.333 & Resistant \\
\hline Hybrid & Susceptible & 4.757 & Moderately resistant \\
\hline Hybrid & Susceptible & 3.02 & Resistant \\
\hline Hybrid & Susceptible & 5.507 & Moderately resistant \\
\hline Hybrid & Susceptible & 5.393 & Moderately resistant \\
\hline Hybrid & Susceptible & 3.45 & Resistant \\
\hline Hybrid & Susceptible & 5.683 & Moderately resistant \\
\hline Hybrid & Susceptible & 3.147 & Resistant \\
\hline Hybrid & Susceptible & 4.81 & Moderately resistant \\
\hline OPV & Resistant & 6.197 & Moderately susceptible \\
\hline OPV & Resistant & 5.417 & Moderately resistant \\
\hline OPV & Resistant & 3.623 & Resistant resistant \\
\hline OPV & Resistant & 1.797 & Resistant \\
\hline OPV & Resistant & 4.257 & Moderately resistant \\
\hline OPV & Resistant & 3.347 & Resistant \\
\hline OPV & Resistant & 5.137 & Moderately resistant \\
\hline OPV & Susceptible & 4.32 & Moderately Resistant \\
\hline OPV & Susceptible & 3.017 & Resistant \\
\hline OPV & Susceptible & 2.343 & Resistant \\
\hline OPV & Susceptible & 3.927 & Resistant \\
\hline OPV & Susceptible & 2.717 & Resistant \\
\hline OPV & Susceptible & 6.02 & Moderately susceptible \\
\hline OPV & Susceptible & 3.457 & Resistant \\
\hline OPV & Susceptible & 1.377 & Resistant \\
\hline Landrace & Unclassified & 4.177 & Moderately Resistant \\
\hline Landrace & Unclassified & 2.617 & Resistant \\
\hline Hybrid & Susceptible check & 9.11 & Susceptible \\
\hline Mean & & 3.772 & \\
\hline LSD (5\%) & & 3.73 & \\
\hline
\end{tabular}

The classification was based on the Dobie index 
were consumed against the experimental mean of $2.5 \mathrm{~g}$. Grain weight loss values might have been higher than those obtained in this study if the weevils had been only young ones, 0 to 3 weeks. In his extensive experiments on the subject of maize weevil resistance, Dobie $(1974 ;$ 1977) demonstrated that the fecundity and feeding of the maize weevils is highest when they are in the age range of 0 to 3 weeks after which there is a steady decline. Since the weevils that were used in this experiment were of unknown age, it is possible that some of them were older than the optimum age for feeding and reproduction.

Dobie index of susceptibility. The range of values of indices obtained in this experiment ( 0.77 to 9.11) was lower than those obtained by other investigators. Arnason et al. (1994) obtained indices as high as 14 in susceptible varieties. One possible explanation is that the previous studies dealt with much more susceptible genotypes than in this experiment. Another cause could be the differences in moisture content. Most researchers infest their samples at about 14\% moisture content. For instance, the maize samples that Arnason et al. (1994) used in Canada had moisture content ranging from 10.4 to $14.90 \%$. The Dobie Index of Susceptibility from such maize samples then ranged from 0 for a resistant check to 15.2 for a susceptible check. The maize samples in the present study had moisture content of 10.5 to 12.5 percent.

The Entomology Research Team at CIMMYT, Mexico, conducted a study to quantify the relationship between grain moisture content, kernel hardness, and resistance to $S$. zeamais and the larger grain borer Prostephanus trancatus (Coleoptera: Bostrichidae) (Bergvinson, 2001). They found that for grain moisture content below $12 \%$, the resistant genotype, population 84 , provided effective control for both insect species. However, once the moisture content reached $16 \%$, the resistant (population 84) and susceptible (CML 244xCML349) entries showed similar damage levels.

The age of weevils in the bioassay might also have contributed to the lower indices. Previous studies (Dobie, 1974) have shown that the fecundity of weevils is highest when they are 0 21 days old.

The resistance/susceptibility of the genotypes in this study matched the classification of CIMMYT to a great extent in the case of hybrids, whereby 15 out of the 17 hybrids classified as resistant by CIMMYT were still found to be resistant

However, there was no definite pattern for OPVS. This could be attributed to the variability in character of the OPVs. It was observed during the study that some OPVs had a mixture of normal white grain and some contained anthocyanin, and/or flint, as well as dent grain. The departure from the CIMMYT classification observed in some genotypes could be due to the effect of environment. Kim and Kossou (2003) studied the response and genetics of maize germplasm resistant to the maize weevil in Nigeria and found highly significant $(\mathrm{P}<0.01)$ data of crosses $\mathrm{x}$ location interactions for number of egg plugs, $F_{1}$ weevils, damaged kernels and percent weevil survival. They concluded that the interactions indicated environmental effects on maize weevil resistance to weevils. Similarly, Duarte et al. (2005), in a study of nitrogen effects on grain quality of Brazilian maize genotypes, found that nitrogen application increased kernel hardness and decreased breakage susceptibility to a minor extent. However, according to these authors, genotype had a much larger influence on grain quality parameters than environment.

\section{ACKNOWLEDGEMENTS}

The authors thank Dr. J. MacRobert and Dr. C. Magorokosho (CIMMYT-Harare ) for supplying the seed for hybrid and open pollinated maize genotypes. Ms E. Namutowe and Ms. F.K Silutongwe, farmers of Mbala District in Zambia provided the seed for the land races. The Maize Research Team of the Zambia Agricultural Research Institute (ZARI) assisted in raising the maize materials for the study. Funding for this research was provided by the Rockefeller Foundation as a scholarship to the principal author to undertake a Masters degree course at the University of Zambia. 


\section{REFERENCES}

Arnason, J.T., Baum, B., Gale, J., Lambert, J.D.H., Bergvinson, D., Philogene, B.J.R.,Serratos, J.A., Mihm, J., and Jewell, D.C. 1994. Variation in resistance of Mexican landraces of maize to maize weevil Sitophilus zeamais, in relation to taxanomic and biochemical parameters. Euphytica 74:227-236.

Arnason, J.T., Conilh de Beyssac, B., Philogene, B.J.R., Bergvinson, D., Serratos, J.A. and Mihm, J.A. 1997. Mechanisms of resistance in maize grain to the maize weevil and the larger grain borer. In: Mihm, J.A. (Ed.), pp. 91-95. Insect Resistant Maize.- Recent Advances and Utilization. A Proceedign of an International Symposium, Mexico City. 27 Nov.-3 Dec. 1994. CIMMYT, Mexico City.

Asawalam, E.F. and A. Hassanali, A. 2006. Constituents of the essential oil of Vernonia amygdalina as maize weevil protectants. Tropical and Sub-tropical Agro-ecosystems 6:95-102.

Baker, J.R. (Ed.). 2007. Insect and related Pests of shrubs: Some important, common and potential pests in Southeastern United States. Center for Integrated Pest Management, North Carolina State University. URL: http:// IPM.ncsu.edu. Retrieved $12^{\text {th }}$ October 2007.

Bekele, J. and Hassanali, A. 2001. Blend effects in the toxicity of the essential oil constituents of Ocimum kilimandscharicum and Ocimum kenyense (Labiateae) on two post-harvest insect pests. Phytochemistry 57: 385-391.

Bergvinson, D.J. 2001. Storage pest resistance in maize. In: Maize programme. Maize research highlights 1999-2000. CIMMYT, MexicoD.F., Mexico. pp. 32-39.

Cardwell, K.F., J.G. Kling, B. Maziya-Dixon, and N.A. Bosque-Pérez, N.A. 2000. Interactions between Fusarium verticillioides, Aspergillus flavus, and insect infestation in four maize genotypes in lowland Africa. Phytopathology 90:276-284.

Danho, M., Casper, C. and Haubruge, E. 2002. The impact of grain quantity on the biology of Sitophilus zeamais Motschulsky (Coleoptera: Curculionidae): oviposition, distribution of eggs, adult emergence, body weight and sex ratio. Journal of Stored Products Research 38:259-266.

Derera, J., Pixley, V. and Giga, D.P. 2001. Resistance of maize to the maize weevil. I. Antibiosis. African Crop Science Journal 9:431-440.

Dhliwayo, T. and Pixley, K.V. 2002. Breeding for resistance to the maize weevil (Sitophilus Zeamais Motsch.): Is it feasible? In: Seventh Eastern and Southern Africa Regional Maize Conference 11th- $15^{\text {th }}$ February, 2001. pp. 134-138.

Dhliwayo, T. and Pixley, K.V. 2003. Divergent selection for resistance to maize weevil in six maize populations. Crop Science 43:20432049.

Dobie, P. 1974. The laboratory assessment of the inherent susceptibility of maize varieties to post-harvest infestation by Sitophilus zeamais. Journal of Stored Product Research 10:183-197.

Dobie, P. 1977. The contribution of the tropical stored products centre to the study of insect resistance in stored maize. Tropical Stored Products Information 34:7-22.

Duarte, A.P., Mason, S. C., Jackson D. S. and J. C. Kiehl. 2005. Grain quality of Brazilian maize genotypes as influenced by nitrogen level. Crop Science 45:1958-1964.

FAO. 1998. World reference base for soil resources. World Soil Resources Reports No. 84.

Freed, R.D., Eisensmith, S.P.,Goetz,S., Reicosky, D., Smail, V.W. and Wolberg, P. 1988. Mstac (Version 1.3). A microcomputer program for the design, management, and analysis of agricultural research experiments. Michigan State University.

Garcia-Lara S., Bergvinson, D. J., Burt, A. J., Ramputh A. I., Diaz-Pontones, D. M. and Arnason, J.T. 2004. The role of pericarp cell wall components in maize weevil resistance. Crop Science 44: 1546 - 1552.

Giles, P.H. and Ashman, F. 1971. A study of preharvest infestation of maize by Sitophilus zeamais (Motschulsky) (Coleoptera: Curculionidae) in the Kenyan Highlands. Journal of Stored Products Research 7:69-83 Gudrups, I., Floyd S., Kling J. G., Bosque-Perez, N. A. and Orchard, J. E. 2001.A comparison of 
two methods of assessment of maize varietal resistance to the maize weevil, Sitophilus zeamais Motschulsky, and the influence of kernel hardness and size on susceptibility. Journal of Stored Products Research 37:287302

Kang, M.S., Zhang,Y and Magari, R. 1995. Combining ability for maize weevil preference of maize grain. Crop Science 35:1556-1559.

Kim, S.K. and Kossou, D.K. 2003. Responses and genetics of maize germplasm resistant to the maize weevil Sitophilus zeamais Motschulsky in West Africa. Journal of Stored Products Research 39:489-505

Kossou, D.K., Mareck, J.H. and Bosque-Perez, N.A. 1993. Comparison of improved and local maize varieties in the Republic of Benin with emphasis on susceptibility to Sitophilus zeamais Motschulsky. Journal of Stored Products Research 29:333-343

Leuschner, K., Monyo E.S., Chinhema, E., Tembo, E. and Martin, D. 2000. Pearl millet grain size and hardness in relation to resistance to Sitophilus Oryzea (L.) (Coleoptera: Curculionidae). African Crop Science Journal 8:77-84.

Montgomery, D.C. 2001. Design and Analysis of Experiments. $5^{\text {th }}$ edition. John Wiley \& Sons, Inc. Singapore.

Munjoma, S. 2004. Comparison of maize inbred line per se and test cross performance for maize weevil (Stophilus Zeamais Motsch) resistance. M.Sc. Thesis. University of Zimbabwe, Harare, Zimbabwe.

Pendleton, M.W., Ellis, E.A., Nchitio, F.M. and B.B. Pendleton, B.B. 2005. Comparison of morphology of sorghum grain to resistance to maize weevil Sitophilus zeamais. Microsc Microanal 11 (Suppl2), 2005.
Pingali, P.L. (Ed.). 2001. CIMMYT 1999-2000 World maize facts and trends. Meeting world maize needs: Technological opportunities and priorities for the public sector. Mexico, D.F.: CIMMYT.

Pixley, K.V. 1997. CIMMYT Mid-altitude maize breeding programme. In: CIMMYT-Zimbabwe Annual Research Report, 1996/97. pp 7-13.

Poehlman, J.M. and Sleper, D.A. 1995. Breeding Field Crops $\left(4^{\text {th }}\right.$ Ed.). Iowa state University Press.

Serratos, J. A., Blanco-Labra A., Mihm J. A., Pietrzak L. and Arnason, J. T. 1993. Generation means analysis of phenolic compounds in maize grain and susceptibility to maize weevil Sitophilus zeamais infestation. Canadian Journal of Botany 71: 1176-118.

Ti jmons, J.C. (Ed.). 1988. Manual for Soil Profile Description. Technical Guide No. 17. Ministry of Agriculture and Water Development. Soil Survey Unit. Government Printer. Lusaka, Zambia.

Ungunantwiwat, A. and Mills, R.B. 1979. Influence of medium and physical disturbances during rearing on development and numbers of Sitophilus progeny. Journal of Stored Products Research. pp. 37-42.

Vivek, B., Bänziger, M. and Pixley, K.V. 2005. Characterization of maize germplasm grown in eastern and southern Africa: Resuilts of the 2004 regional trials coordinated by CIMMYT. Harare, Ziombabwe. CIMMYT. 68pp.

Zulu, B., Nijhoff J.J., Jayne T.S. and Negassa, A. 2000. Is the glass half-empty or half-full? An analysis of agricultural production trends in Zambia. Working Paper No. 3. Food Security Research Project, Lusaka Zambia. (http:// www.aec.msu.edu/egecon/fs2/zambia/ index.htm). 